JHLSTE

Journal of Hospitality, Leisure,

Sport \& Tourism Education

Vol. 6, No. 1.

ISSN: 1473-8376

www.hlst.heacademy.ac.uk/johlste

ACADEMIC PAPER

\title{
Career Perceptions of Undergraduate Tourism Students: A Case Study in Turkey
}

\author{
Sevgin Akış Roney (sevgin @ boun.edu.tr) \\ School of Applied Disciplines, Department of Tourism Administration, \\ Boğaziçi University, Hisar Campus, Bebek 34342, Istanbul, Turkey \\ Perin Öztin (oztin@ billkent.edu.tr) \\ School of Applied Technology and Management, Tourism and Hotel Management Department, \\ Bilkent University, Bilkent 06800, Ankara, Turkey
}

10.3794/johlste.61.118

@ Journal of Hospitality, Leisure, Sport and Tourism Education

\begin{abstract}
The characteristics of tourism employment and careers have been widely documented. Although the development of the tourism industry can create new employment opportunities, it is often criticised for providing primarily low-skilled and low-paying jobs. If today's students are to become the effective practitioners of tomorrow, it is fundamental to understand their perceptions of tourism employment. This paper focuses on a sample of 450 Turkish students studying tourism at university level in order to analyse their perceptions towards tourism careers. The results showed that, overall, the respondents' perceptions are neither favourable nor unfavourable. The findings also indicated that: willingness to study tourism; willingness to work in tourism after graduation; and work experience; are important factors in shaping their image of tourism careers.
\end{abstract}

Keywords: Students' Perceptions, Tourism Careers, Turkey

Sevgin Aklş Roney is a full time faculty member of the Tourism Administration Department at Boğaziçi University in Istanbul. She worked as a Visiting Professor at Montana State University, and a full time faculty member at Eastern Mediterranean University, Bilkent University and Işılk University at various times. Her publications focus mainly on perceptions of tourism development, impacts of tourism, sustainable tourism, and internet use in tourism. She gained her BA Business Administration from Boğaziçi University, and her MA and PhD from the Faculty of Economics at Istanbul University.

Perin Öztin is currently the Dean of Students at Bilkent University and also a faculty member of the Department of Tourism \& Hotel Management at the same university in Ankara. Her main interest areas are cultural tourism, tangible heritage, tourist attractions of Turkey, curriculum development, tour designing, and student coaching. She earned an BA in Business Administration at Dokuz Eylül University and MBA at Alaska Pacific University. 


\section{Introduction}

Tourism is a rapidly growing industry and a major source of employment. A principal argument made for encouraging the development of tourism is that it produces a considerable number of jobs, both directly in the sectors in which tourist expenditure occurs and more widely via inter-industry linkages. The growth of tourism and related employment is seen as part of the broad shift from a manufacturing to a service economy in many developed and developing countries around the world. However, even though development of the tourism industry creates new employment opportunities, it is often criticised as generating low-skilled and low-paying jobs that offer little job satisfaction. Consequently, the tourism industry has a reputation for high staff turnover and a waste of trained personnel.

The tourism industry began to develop in Turkey in the early 1980s when the government liberalised the foreign trade regime in order to promote economic prosperity. The 1990s witnessed rapid liberalisation. The Tourism Encouragement Law, decreed in 1982, set the legal basis for the acceleration of the development of inbound tourism in Turkey by providing a number of vital instruments to both Turkish and foreign tourism investors. This led to an oversupply of accommodation, which resulted in the decline of room rates in foreign markets, an increasing shortage of skilled staff and also a significant degree of environmental disruption. Today, Turkey is a cheap mass-tourism version of "sea, sand and sun" compared with other Mediterranean destinations.

Even though there is no recent data available on tourism industry employment in Turkey (partly because of the difficulty of measuring the industry's contribution to the total employment), according to the TÜRSAB (Association of Turkish Travel Agencies), the share of direct employment in tourism within total employment was $5.1 \%$ in 2001, whereas the share in Greece was approximately four times more for the same period (TÜRSAB, 2004).

In the 1990s, to overcome the shortage of skilled staff, the Turkish Government, through the Council for Higher Education, initiated a strategy to strengthen the provision of tourism education and encouraged the development of two-year and four-year Vocational Schools within the body of different universities (Brotherton et al., 1994). Currently there are 31 universities in Turkey that offer a four-year programme of tourism and hotel management (Akademik Turizm Bülteni, 2006) and there are around ninety two-year programmes (ÖSYM, 2005). Whilst the two-year Vocational Schools are distributed all over Turkey, the four-year programmes are concentrated mostly in the western part of Turkey, which is economically more developed and receives the majority of tourists.

Since the continued prosperity of tourism depends, to a large extent, on the employment of well educated, motivated and committed people, who are satisfied with their jobs, it is important to provide qualified tourism students with a positive attitude towards work in the tourism industry. This paper focuses on a sample of 450 Turkish undergraduate students studying tourism and analysis of their perceptions towards tourism careers.

\section{Literature Survey}

Although there is substantial literature about tourism employment, only a limited number of studies were conducted to highlight the perceptions of students towards careers in the tourism industry. This means that more empirical studies focusing on tourism students' perceptions of the industry are needed in order to evaluate the status of tourism jobs in the human resources (HR) planning process for the tourism sector. Generally, HR plans focus on the employment needs of large international tourism companies, especially in hospitality, and neglect perceptions of students. Negative attitudes towards working in tourism may result in the industry's failure to capture and retain the most qualified tourism students. Since the tourism industry relies so heavily on people to deliver a service, this would result in a negative impact on service quality and consumer satisfaction, which might then hinder the competitiveness of the industry. 
Several researchers have surveyed the perceptions of secondary or high school students towards employment in the tourism industry. In his study of secondary school students in Australia, Ross (1994) found a high level of interest in management positions in the tourism industry. Getz (1994) surveyed high school students in the Spey Valley in Scotland. His longitudinal study showed that perceptions towards a potential career in tourism had become much more negative over a period of 14 years. Airey and Frontistis (1997) compared the attitudes of secondary school students towards tourism careers in Greece and the United Kingdom. They showed that the UK students had a less positive attitude towards tourism than their Greek counterparts. At the end of their survey of high school students in Arizona, Cothran and Combrink (1999) stated that although minority students often had less knowledge about hospitality jobs, they had more interest in them.

Several researchers have also studied the perceptions of undergraduate tourism and hospitality management students. Casado's survey (1992) on student expectations of hospitality jobs revealed that, although they tended to be fairly realistic before their graduation, the turnover of these students seemed to be high. Barron and Maxwell (1993) examined the perceptions of new and continuing students at Scottish higher education institutions. They found that in general the new students had positive images of the industry, whereas the students with supervised work experience were much less positive in their views. Purcell and Quinn (1995) surveyed 704 former tourism students and discovered that graduates complained of having little opportunity to develop their managerial skills. A relatively recent study, conducted by Kuşluvan and Kuşluvan (2000), of four-year tourism and hotel management students, in seven different schools in Turkey, reported negative perceptions towards different dimensions of working in tourism. Kozak and Kizılırmak (2001) carried out a similar survey among the undergraduate tourism students in three different vocational schools in Turkey. Like Barron and Maxwell, they too indicated that work experience as a trainee in the industry affected their perceptions in a negative way. In his comparative study of hospitality students' future perceptions at two different universities in the UK and in the Netherlands, Jenkins (2001) also showed that, as they progress in their degree, the students' perceptions of the industry tend to deteriorate.

Birdir (2002) surveyed those junior and senior tourism students at the University of Mersin in Turkey in order to find out the reasons why some students were not eager to work in the industry after graduation. The main reason stated was the lack of quality education in tourism to enable them to be successful in the sector. Irregular working hours in tourism was the second major reason. Another study, conducted among the tourism students of Adnan Menderes University in Turkey, examined what tourism and hospitality internship students expect from working in the industry (Yüksel et al., 2003). The results showed that internship students gave high priority to: good and fair wages; opportunities for career development; tactful and professional management; and personal growth. The findings of the survey conducted by Gökdeniz et al. (2002), at 4-star and 5-star hotels in Turkey, showed that one of the reasons for the enduring poor image of the industry is the managers' attitudes towards the trainees. Most of the managers used the trainees because they were "cheap labour" and put these students into work in any department where staff were needed.

Finally, the most recent survey, conducted by Aksu and Köksal (2005) at the Akdeniz University School of Tourism and Hotel Management in Antalya, investigated the main expectations of students from the tourism industry. The results indicated that generally they had low expectations. However, positive perceptions were found among respondents who had: chosen the school as one of their top three choices at the university entrance exam; chosen the school willingly; and carried out practical work experience outside of Turkey.

\section{Objective and Methodology of the Study}

In order to examine the career perceptions of undergraduate tourism students in Turkey, three of the 31 universities which offer a four-year programme of tourism and hotel management were surveyed: the Department of Tourism Administration (DTA) of the School of Applied Disciplines at Boğaziçi University in Istanbul, the Tourism and Hotel Management Department (THM) of the School of Applied Technology and Management at Bilkent University in Ankara, and the School of Tourism and Hotel Management (STHM) at Anadolu University in Eskişehir. 
The medium of instruction at the first two is English, which gives them a significant advantage over the others. Because DTA and THM were not covered in the previous studies and are preferred by many of the students, it was considered essential to include students from these institutions in order to create a better overall picture of student perceptions of the industry. The third institution was chosen because it is one of the oldest and best-known tourism schools in Turkey.

A total of 300 questionnaires were distributed equally in the classrooms at Boğaziçi and Bilkent Universities during the spring semester of 2005, and a set of 150 at Anadolu University in June 2005. All the questionnaires were returned and the results then analysed. Students at all levels were included, from freshman to senior.

In order to achieve a 95\% confidence level and a 5\% sampling error (with the most conservative response format of $\mathrm{p}=.50$ and $\mathrm{q}=.50$ ), the required sample size is 384 (Mann, 1998:407). In our study the number of respondents was 450 , which corresponds to a sampling error of $4.6 \%$, (instead of 5\%).

The questionnaire (included in the Appendix) was developed primarily by integrating questions and statements used in some of the previous studies mentioned in the literature survey (Airey and Frontistis, 1997; Kuşluvan and Kuşluvan, 2000; Jenkins, 2001; Kozak and Kızılırmak, 2001; Birdir, 2002; Aksu and Köksal, 2005). It was composed of two sections. The first section was comprised of 13 questions designed to elicit the characteristics of the respondents. The second section contained a set of 12 statements about career perceptions.

A 5-point Likert Scale (strongly agree $=5$; agree $=4$; neither agree nor disagree $=3$; disagree $=2$; strongly disagree $=1$ ) was used to measure the respondents' degree of agreement or disagreement with various statements given, to assess relevant perceptions. Five statements that reflected negative perceptions were reverse coded (during the coding step of the analysis) to prevent the response set bias.

For the group of 12 statements about career perceptions, the coefficient of internal consistency of the total scale reliability (Cronbach's alpha) was calculated as .71. According to Sekaran (2003), coefficients less than .60 are considered to be 'poor', those in the .70 range 'acceptable', and those over .80 'good'. Thus, the internal consistency of the statements used in this study can be considered to be acceptable.

\section{Findings of the Survey}

\section{Profile of the Survey Sample}

The answers given to the questions asked in the first section of the questionnaire are presented in the first three tables.

As can be seen in Table 1, there were an equal number of respondents studying at Boğaziçi, Bilkent, and Anadolu Universities, as arranged by the researchers. The gender split was almost equal: $48.7 \%$ females and $51.3 \%$ males. However, analysis of the distribution of respondents according to class revealed that the number of sophomores and juniors was higher than freshmen and seniors. This reflects the actual distribution of students at these universities - the number of sophomore and junior students is always higher.

\begin{tabular}{l|c|c}
\hline \hline Profile & Frequency & Percentage \\
\hline \hline Name of the university & 150 & 33.33 \\
\hline Boğaziçi & 150 & 33.33 \\
\hline Bilkent & 150 & 33.33 \\
\hline Anadolu &
\end{tabular}


Aklş Roney and Öztin (2007) Career Perceptions of Undergraduate Tourism Students: A Case Study in Turkey

\begin{tabular}{|c|c|c|}
\hline \multicolumn{3}{|l|}{ Gender of the students } \\
\hline Female & 219 & 48.7 \\
\hline Male & 231 & 51.3 \\
\hline \multicolumn{3}{|l|}{ Class of the students } \\
\hline Freshman & 83 & 18.4 \\
\hline Sophomore & 138 & 30.7 \\
\hline Junior & 134 & 29.8 \\
\hline Senior & 95 & 21.1 \\
\hline \multicolumn{3}{|c|}{ Completed vocational school of tourism and hotel management } \\
\hline Yes & 130 & 28.9 \\
\hline No & 320 & 71.1 \\
\hline \multicolumn{3}{|c|}{ Willingness to study tourism at the university } \\
\hline Yes, I was willing & 291 & 64.7 \\
\hline I was not very willing & 63 & 14 \\
\hline No, I was not willing at all & 96 & 21.3 \\
\hline
\end{tabular}

Rank of preference of the enrolled tourism and hotel management school in the university entrance exam

\begin{tabular}{l|c|c}
\hline Between 1-5 & 364 & 81 \\
\hline Between 6-10 & 60 & 13.3 \\
\hline Between 11-15 & 15 & 3.3 \\
\hline 16 and lower & 11 & 2.4 \\
\hline Practical work experience in the tourism industry \\
\hline Yes & 343 & 76.2 \\
\hline No & 107 & 23.8 \\
\hline Intention to work in the tourism industry after graduation \\
\hline Yes & 295 & 65.6 \\
\hline No & 40 & 8.9 \\
\hline Undecided & 115 & 25.6 \\
\hline Friends / relatives who work in the tourism industry \\
\hline There are & 196 & 43.6 \\
\hline There are not & 254 & 56.4 \\
\hline
\end{tabular}

Table 1: Respondents' Profiles $(n=450)$

Table 1 also shows that although a small proportion (28.9\%) of the respondents had attended a vocational school of tourism and hotel management at secondary school level, $81 \%$ of them indicated that tourism departments at Boğaziçi, Bilkent, and Anadolu Universities were among their top five preferences (i.e. between 1 and 5, out of 16) in the university entrance exam. The proportion of respondents who were willing to study tourism at the university $(64.7 \%)$ was almost equal to the proportion of those who wanted to work in the tourism industry after graduation (65.6\%). The same table shows that $76.2 \%$ of the respondents had practical work experience in the tourism sector, 99 working days on average. Finally, $43.6 \%$ of the respondents answered in the positive to the question of whether they have friends/relatives who work in tourism.

\begin{tabular}{l|c}
\hline \hline Type of business & Frequency \\
\hline \hline Hotel & 296 \\
\hline Holiday village & 64 \\
\hline Travel agency / Tour operator & 65 \\
\hline
\end{tabular}


Akış Roney and Öztin (2007) Career Perceptions of Undergraduate Tourism Students: A Case Study in Turkey

\begin{tabular}{l|c}
\hline Airline company & 5 \\
\hline Restaurant / Bar & 30 \\
\hline Other & 12 \\
\hline
\end{tabular}

Table 2: Types of tourism related businesses where respondents worked as trainees $(\mathrm{n}=343)$

* Response categories are not mutually exclusive since the same student can work at different tourism related businesses during different periods of his/her training.

Table 2 shows the different types of tourism related businesses where respondents worked as trainees. The majority of the respondents preferred to work at hotels (296 respondents). Travel agencies/tour operators and holiday villages were their second choice (65 and 64 respondents, respectively).

Table 3 indicates that their preferences for working in specific tourism sectors after graduation were similar to their choices as trainees. Mostly they preferred the accommodation sector (161 respondents), followed by travel agencies/tour operators (84 respondents), and finally food and beverage (60 respondents). Answers given to the open-ended question, "five years after graduation, which level of position do you expect to have?", revealed that students who want to work in the food and beverage sector, generally hope to be owners of their own businesses. In general, responses given to this question were quite ambitious. The majority of the students expected to be either a general manager or a department manager within five years. However, there was a range, with "highest position possible" and "lowest level of operational worker" at the two extremes.

\begin{tabular}{l|c}
\hline \hline Type of tourism sector & Frequency \\
\hline \hline Accommodation & 161 \\
\hline Travel agency / Tour operator & 84 \\
\hline Air transportation & 23 \\
\hline Food and beverages & 60 \\
\hline Entertainment & 14 \\
\hline Other & 10 \\
\hline
\end{tabular}

Table 3: Preferences for working in specific tourism sectors after graduation $(\mathrm{n}=295)$

* Response categories are not mutually exclusive.

\section{Perceptions of tourism careers}

Table 4 shows details of the degrees of agreement with each one of the 12 statements provided in the second part of the questionnaire. For simplicity, perceptions are summarised in group percentages as "strongly agree and agree" and "strongly disagree and disagree". The overall mean value was 3.09 out of 5, which means the perception of the respondents towards tourism careers, in general, was neither favourable nor unfavourable. This can also be seen from the responses given to the final statement "in general, the advantages of working in the tourism industry outweigh the disadvantages". Almost half of the respondents $(49.2 \%)$ agreed with this statement, and the other half was either indecisive $(31.1 \%)$ or disagreed $(19.7 \%)$.

\begin{tabular}{l|c|c|c|c|c}
\hline \hline $\begin{array}{l}\text { How much do you agree or disagree with } \\
\text { each statement? }\end{array}$ & $\begin{array}{c}\text { Strongly } \\
\text { agree / } \\
\text { agree }\end{array}$ & $\begin{array}{c}\text { Neither } \\
\text { agree nor } \\
\text { disagree }\end{array}$ & $\begin{array}{c}\text { Strongly } \\
\text { disagree / } \\
\text { disagree }\end{array}$ & $\begin{array}{c}\text { Mean } \\
(\bar{x})\end{array}$ & $\begin{array}{c}\text { Standard } \\
\text { deviation } \\
(\mathbf{s})\end{array}$ \\
\hline \hline $\begin{array}{l}\text { Meeting new people by working in tourism is a } \\
\text { pleasant experience. }\end{array}$ & $90 \%$ & $5.3 \%$ & $4.7 \%$ & 4.53 & .87 \\
\hline $\begin{array}{l}\text { One can make good money by working in } \\
\text { tourism. }\end{array}$ & $70.6 \%$ & $15.8 \%$ & $13.6 \%$ & 3.84 & 1.06 \\
\hline $\begin{array}{l}\text { To study tourism management at the university } \\
\text { level is a correct investment in career } \\
\text { development. }\end{array}$ & $67.3 \%$ & $13.1 \%$ & $19.6 \%$ & 3.78 & 1.19 \\
\hline \begin{tabular}{l} 
Promotion opportunities are satisfactory in the \\
\hline
\end{tabular} & $58.2 \%$ & $15.1 \%$ & $26.7 \%$ & 3.42 & 1.10 \\
\hline
\end{tabular}


Aklş Roney and Öztin (2007) Career Perceptions of Undergraduate Tourism Students: A Case Study in Turkey

\begin{tabular}{|c|c|c|c|c|c|}
\hline tourism industry. & & & & & \\
\hline $\begin{array}{l}\text { In general, the advantages of working in the } \\
\text { tourism industry outweigh the disadvantages. }\end{array}$ & $49.2 \%$ & $31.1 \%$ & $19.7 \%$ & 3.38 & 1.06 \\
\hline $\begin{array}{l}\text { It is not necessary to have a university degree to } \\
\text { work in the tourism industry. } \mathrm{R}^{*}\end{array}$ & $42.4 \%$ & $13.8 \%$ & $43.8 \%$ & 3.08 & 1.42 \\
\hline $\begin{array}{l}\text { Working in tourism does not provide a secure } \\
\text { future. } \mathrm{R}^{*}\end{array}$ & $43.5 \%$ & $20 \%$ & $36.5 \%$ & 2.89 & 1.25 \\
\hline There is no sexual discrimination in tourism. & $33.5 \%$ & $18 \%$ & $48.5 \%$ & 2.79 & 1.29 \\
\hline $\begin{array}{l}\text { Tourism related jobs are more respected than } \\
\text { the other jobs. }\end{array}$ & $25.1 \%$ & $27.1 \%$ & $47.8 \%$ & 2.70 & 1.06 \\
\hline It is hard to find job security in tourism. $\mathrm{R}^{*}$ & $64.7 \%$ & $13.3 \%$ & $22 \%$ & 2.40 & 1.12 \\
\hline $\begin{array}{l}\text { Since many of the managers in tourism do not } \\
\text { have a university degree, they are jealous of } \\
\text { university graduates working in the industry. } \\
\mathrm{R}^{*}\end{array}$ & $62.5 \%$ & $21.1 \%$ & $16.4 \%$ & 2.34 & 1.08 \\
\hline $\begin{array}{l}\text { Irregular working hours in tourism affect family } \\
\text { life negatively. } \mathrm{R}^{*}\end{array}$ & $79.3 \%$ & $8.9 \%$ & $11.8 \%$ & 1.91 & 1.09 \\
\hline
\end{tabular}

Table 4: Perceptions of tourism students concerning careers in the tourism industry $(\mathrm{n}=450)$ $R^{*}$ : these items are reverse coded

As can be seen in Table 4, 90\% of the respondents agreed with the statement "meeting with new people by working in tourism is a pleasant experience" $(\bar{x}=4.53)$, while $70.6 \%$ of the respondents agreed with the statement "one can make good money by working in tourism" ( $\bar{x}=3.84)$. "Promotion opportunities are satisfactory in the tourism industry" was another statement that $58.2 \%$ of the respondents agreed with, giving a comparatively high mean value $(\bar{x}=3.42)$. On the other hand, more than half of the respondents $(67.3 \%)$ believed that "to study tourism management at the university level is a correct investment in career development", while $43.8 \%$ of them disagreed with the negative statement "it is not necessary to have a university degree to work in the tourism industry".

It seems that the majority of the respondents did not believe that tourism is a prestigious vocation in the society as shown by the low percentage $(25.1 \%)$ of those who agreed with the statement "tourism related jobs are more respected than the other jobs". "Irregular working hours in tourism affect family life negatively" was answered in the affirmative by the $79.3 \%$ of the respondents. It is true that many tourism workers work long and unsociable hours when the rest of the population does not.

Job security was another problem. It is well known that according to Maslow's 'hierarchy of needs' theory, safety and security (together with physiological needs) are the primary needs that must be satisfied before the secondary needs (belonging, self-esteem and self-actualisation) become active sources of motivation. However, employment in the tourism industry is notoriously insecure because of seasonality, fluctuations in demand, and the high number of part-time and temporary jobs (Bull, 1995). Therefore, it was not surprising that $64.7 \%$ of the respondents agreed that "it is hard to find job security in tourism" while $43.5 \%$ of them believed that "working in tourism does not provide a secure future".

The existence of sexual discrimination was another issue that was noted by $48.5 \%$ of the respondents, while $18 \%$ of them were undecided. Interestingly, there was no great difference between female $(\bar{x}$ $=3.42)$ and male $(\bar{x}=2.77)$ students $(\mathrm{t}=.275$ and $\mathrm{p}=.784)$ in their perceptions. Finally, the proportion of the respondents who agreed with the statement "since the majority of the managers in tourism do not have a university degree, they are jealous of university graduates working in the industry" was quite high $(62.5 \%)$. 
Akış Roney and Öztin (2007) Career Perceptions of Undergraduate Tourism Students: A Case Study in Turkey

\section{Comparisons of career perceptions}

As can be seen in Table 5, there was no significant gender-based difference in the perception of tourism careers.

\begin{tabular}{c|c|c|c}
\hline \hline $\begin{array}{c}\text { Female } \\
(\mathbf{n}=219)\end{array}$ & $\begin{array}{c}\text { Male } \\
(\mathbf{n}=\mathbf{2 3 1})\end{array}$ & t value & $\begin{array}{c}\text { Sig. } \\
(\text { 2-tailed })\end{array}$ \\
\hline \hline $\bar{x}=3.09$ & $\bar{x}=3.08$ & 0.197 & 0.844 \\
$\mathrm{~s}=0.54$ & $\mathrm{~s}=0.57$ & & \\
\hline
\end{tabular}

Table 5: Comparison of the mean scores of career perceptions between female and male students $(\mathrm{n}=450)$

This finding is compatible with the finding of a previous survey conducted by Kozak and Kızılırmak (2001) among undergraduate tourism students in Turkey.

Similarly, the results given in Table 6 show that there was also no statistically significant difference between the career perceptions of the respondents who have friends/relatives working in the tourism industry and those who do not.

\begin{tabular}{c|c|c|c}
\hline \hline $\begin{array}{c}\text { Yes } \\
(\mathbf{n}=\mathbf{1 9 6})\end{array}$ & $\begin{array}{c}\text { No } \\
(\mathbf{n}=\mathbf{2 5 4})\end{array}$ & t value & $\begin{array}{c}\text { Sig. } \\
(\mathbf{2} \text {-tailed })\end{array}$ \\
\hline $\bar{x}=3.14$ & $\bar{x}=3.05$ & 1.810 & 0.071 \\
$\mathrm{~s}=0.49$ & $\mathrm{~s}=0.59$ & & \\
\hline
\end{tabular}

Table 6: Comparison of the mean scores of career perceptions for students with and without any friends/relatives who work in the tourism industry $(n=450)$

However, as indicated in Table 7, there was a significant difference between the perceptions of students at different universities. Post-hoc comparisons made using the Tukey HSD test indicated that the mean score for Bilkent students was significantly different from the mean scores of the groups at Boğaziçi and Anadolu Universities. Bilkent students seemed to have a more positive image of the industry than the rest - a further survey would be required to investigate the reasons for this.

\begin{tabular}{c|c|c|c|c}
\hline $\begin{array}{c}\text { Boğaziçi } \\
(\mathbf{n}=\mathbf{1 5 0})\end{array}$ & $\begin{array}{c}\text { Bilkent } \\
(\mathbf{n}=\mathbf{1 5 0})\end{array}$ & $\begin{array}{c}\text { Anadolu } \\
(\mathbf{n}=\mathbf{1 5 0})\end{array}$ & F value & Sig. \\
\hline \hline $\bar{x}=3.07$ & $\bar{x}=3.25$ & $\bar{x}=2.93$ & 12.73 & 0.000 \\
$\mathrm{~s}=0.48$ & $\mathrm{~s}=0.55$ & $\mathrm{~s}=0.58$ & & \\
\hline
\end{tabular}

Table 7: Comparison of the mean scores of career perceptions for Boğaziçi, Bilkent and Anadolu University students $(n=450)$

Tables 8 and 9 show that willingness to study tourism and intention to work in the tourism industry after graduation were important factors influencing the respondents' perceptions in a positive way. The Post-hoc Tukey HSD test indicated the mean value of the perceptions of the respondents who were willing to study tourism was significantly different from the rest. Their concept of the industry was more favourable than the others. Likewise, post-hoc comparisons indicated that the mean value for those respondents who were interested in working in tourism was significantly higher than the mean scores of the respondents who were either not interested or undecided.

\begin{tabular}{c|c|c|c|c}
\hline \hline $\begin{array}{c}\text { Yes, I was } \\
\text { willing } \\
(\mathbf{n}=\mathbf{2 9 1})\end{array}$ & $\begin{array}{c}\text { No, I was not } \\
\text { very willing } \\
(\mathbf{n}=\mathbf{6 3})\end{array}$ & $\begin{array}{c}\text { No, not at } \\
\text { all }(\mathbf{n}=\mathbf{9 6})\end{array}$ & F value & Sig. \\
\hline $\bar{x}=3.24$ & $\bar{x}=2.69$ & $\bar{x}=2.88$ & 40.51 & 0.000 \\
$\mathrm{~s}=0.49$ & $\mathrm{~s}=0.58$ & $\mathrm{~s}=0.53$ & & \\
\hline
\end{tabular}


Table 8: Comparison of the mean scores of career perceptions for students with different levels of willingness to study tourism $(n=450)$

\begin{tabular}{c|c|c|c}
\hline \hline $\begin{array}{c}\text { Work experience } \\
(\mathbf{n}=\mathbf{3 4 3})\end{array}$ & $\begin{array}{c}\text { No work } \\
\text { experience } \\
(\mathbf{n}=\mathbf{1 0 7})\end{array}$ & t value & $\begin{array}{c}\text { Sig. } \\
(\mathbf{2}-\text { tailed })\end{array}$ \\
\hline \hline $\bar{x}=3.02$ & $\begin{array}{r}\bar{x}=3.29 \\
\mathrm{~s}=0.46\end{array}$ & -4.980 & 0.000 \\
$\mathrm{~s}=0.56$ & $\mathrm{C}$
\end{tabular}

Table 9: Comparison of the mean scores of career perceptions for students with and without work experience $(n=450)$

On the other hand, Table 10 indicates that career perceptions of the respondents change according to their year of study. Post-hoc comparisons made using the Tukey HSD test showed the mean value for freshmen was significantly higher than the mean scores of both juniors and seniors. In other words, as the respondents progress in their degree, their perceptions of the industry deteriorate.

\begin{tabular}{c|c|c|c|c|c}
\hline \hline $\begin{array}{c}\text { Freshman } \\
(\mathbf{n}=\mathbf{8 3})\end{array}$ & $\begin{array}{c}\text { Sophomore } \\
(\mathbf{n}=\mathbf{1 3 8})\end{array}$ & $\begin{array}{c}\text { Junior } \\
(\mathbf{n}=\mathbf{1 3 4})\end{array}$ & $\begin{array}{c}\text { Senior } \\
(\mathbf{n}=\mathbf{9 5})\end{array}$ & F value & Sig. \\
\hline $\bar{x}=3.27$ & $\bar{x}=3.09$ & $\bar{x}=3.01$ & $\bar{x}=3.03$ & 4.44 & 0.004 \\
$\mathrm{~s}=0.52$ & $\mathrm{~s}=0.53$ & $\mathrm{~s}=0.57$ & $\mathrm{~s}=0.56$ & & \\
\hline
\end{tabular}

Table 10: Comparison of the mean scores of career perceptions according to the class of the students $(n=450)$

Similarly, the results given in Table 11 display a statistically significant relationship between work experience and perceptions of tourism careers. It appears that students with work experience tend to have negative attitudes towards tourism jobs. It can be claimed that as students progress in their degree and gain more experience as trainees in the sector, their image of the industry changes for the worse.

\begin{tabular}{c|c|c|c|c}
\hline $\begin{array}{c}\text { Yes } \\
(\mathbf{n}=\mathbf{2 9 6})\end{array}$ & $\begin{array}{c}\text { No } \\
(\mathbf{n}=\mathbf{3 9})\end{array}$ & $\begin{array}{c}\text { Indecisive } \\
(\mathbf{n}=\mathbf{1 1 5})\end{array}$ & F value & Sig. \\
\hline $\bar{x}=3.18$ & $\bar{x}=2.76$ & $\bar{x}=2.94$ & 17.12 & 0.000 \\
$\mathrm{~s}=0.54$ & $\mathrm{~s}=0.52$ & $\mathrm{~s}=0.52$ & & \\
\hline
\end{tabular}

Table 11: Comparison of the mean scores of career perceptions according to the students' intention to work in tourism after graduation $(n=450)$

\section{Interpretation of the findings}

The tourism industry's traditional image of low pay is not supported by the findings of this survey, as $70.6 \%$ of the respondents agreed with the statement "one can make good money by working in tourism". This can be explained by the diversity of tourism related jobs. There is considerable variation in tourism occupations, and consequently there are many instances of well-paid occupations in the industry (Riley et al., 2002). Managers or professionals who are full-time workers enjoy high earnings whereas part-time and temporary workers, who are often semi-skilled or unskilled, tend to earn little money. It seems that, in general, the respondents believed that those who invest in tourism education should earn more than those who do not. Almost two-thirds of them agreed that "to study tourism is a good career investment". According to the answers given to the open-ended question, the majority of the respondents expect to have high-level managerial positions in the industry after graduation and earn good money.

However, as students progress in their studies, and have more work experience as trainees in the industry, their perception of tourism related jobs are affected in a negative way. This finding is in agreement with those of previous studies (Barron and Maxwell, 1993; Getz, 1994; Kuşluvan and 
Kuşluvan, 2000; Kozak and Kızılırmak, 2001; Jenkins 2001; Aksu and Köksal, 2005), which shows that the role of experience in forming perceptions is important.

The individual commitment of the students is another factor that shapes the image of the tourism industry in a positive way. A desire to study tourism at the university and willingness to work in tourism after graduation contribute positively to the overall image of the industry. This finding is in agreement with those of Aksu and Köksal (2005).

The general perception of tourism employment as lower prestige work still prevails. Many tourism jobs are often seen as low skilled and therefore are regarded as demeaning. As indicated above, only a quarter of the respondents agreed with the statement "tourism related jobs are more respected than the other jobs". In spite of the diversity of tourism occupations, the poor image of some occupations automatically transfers to all tourism-related jobs.

After "irregular working hours", which is one of the well-known negative characteristics of tourism employment, "job security" seems to be an important concern for the students. Of course, feeling secure and confident about the future of one's job is an important aspect of employment quality. However, in today's global world, as a result of the fast pace of technological change and outsourcing, labour flexibility has increased and consequently job security became a problem in almost every sector. Labour flexibility has always been a major problem in the tourism industry and nowadays there is an even greater tendency towards irregular working hours and a lack of job security.

\section{Conclusion}

This research focused on the description of the undergraduate tourism students' perceptions of tourism as a profession based on the survey at three different universities in Turkey. In contrast to the findings of the previous research, the results of this survey indicated that the general notion of tourism employment appears to be neither positive nor negative. Even if new students start with a more optimistic view of the industry, after the internship period and (for some students) part-time work experience, they develop a less favourable perception. This may be explained by a lack of sophistication in human resource policies and practices in many tourism businesses. In general, managers are reluctant to encourage empowerment to participate in the decision-making process and to motivate the workforce. Indeed, the common complaint of the Boğaziçi University students at the end of their summer training period is the same: they are not given the opportunity to demonstrate their career potential, but are instead used as cheap labour to do trivial work.

However, in spite of the effect of generally unfavourable working conditions on the respondents' perceptions, their willingness to study tourism, and commitment to work in the industry after graduation, compensate for the unfavourable picture of tourism careers. When students are really interested in studying tourism and pursuing a career in the industry, they tend to have a more realistic view of the nature of tourism related jobs, which means more sensible expectations.

It is known that high career expectations, when they are not met, can create disappointment and consequently, less job satisfaction and high staff turnover. Therefore, if students who are strongminded about attending a four-year programme of tourism are given the chance to do so, there will probably be less frustration in terms of their career prospects.

Unfortunately, within the current education system, students have to take a rigorous central exam given by the Higher Educational Council to enter university, and are then placed at different universities according to their success in the exam results. As a result, they often do not have the chance to study what they really want. This is one of the major problems of the Turkish higher education system in general, and to provide solutions is beyond the scope of this study.

However, even if it is true that most of the career problems occur because of the special characteristics of employment in the tourism industry (such as seasonality and the high amount of part-time and temporary jobs), improving working conditions in the tourism businesses is easier to 
achieve. As indicated above, one of the reasons for the negative image of the industry is the use of outmoded styles of human resource management. High quality professional human resources would help to improve the quality of work experience and, as a consequence, potentially improve the image of the industry. In the long term, the general employment conditions in the industry could be improved to enable today's students, with formal qualifications, to become the effective managers of tomorrow. Therefore, it can be claimed that one of the ways of increasing the share of direct employment in tourism is to increase the supply of well-educated manpower.

\section{Acknowledgement}

The authors would like to thank Assistant Professor Dr Medet Yolal for helping with the field survey at the School of Tourism and Hotel Management at Anadolu University in Eskişehir.

\section{References}

Aksu, A. A. and Köksal, C. D. (2005) Perceptions and attitudes of tourism students in Turkey. International Journal of Contemporary Hospitality Management, 17(5), 436-447.

Airey, D. and Frontistis, A. (1997) Attitudes to careers in tourism: an Anglo Greek comparison. Tourism Management, 18(3), 149-158.

Barron, P. and Maxwell, G. (1993) Hospitality management students' image of the hospitality industry. International Journal of Contemporary Hospitality Management, 5(5), 5-8.

Birdir, B. (2002) Turizm ve otel işletmeciliği eğitimi alan lisans öğrencilerinin turizm endüstrisinde çalışmayı tercih etmemelerinin temel nedenleri: Bir nominal grup tekniği araştırması. In: Ministry of Tourism (ed.), Proceedings of the conference and workshop on tourism education, 495-504. Ankara: Ministry of Tourism Press.

Brotherton, B., Woolfenden, G. and Himmetoğlu, B. (1994) Developing human resources for Turkey's tourism industry in the 1990s. Tourism Management, 15(2), 109-116.

Bull, A. (1995) The economics of travel and tourism (second edition). Melbourne: Longman.

Casado, M.A. (1992) Student expectations of hospitality jobs. Cornell Hotel and Restaurant Administration Quarterly, 33(4), 80-82.

Cothran, C. C. and Combrink, T. E. (1999) Attitudes of minority adolescents toward hospitality industry careers. Hospitality Management, 18, 143-158.

Getz, D. (1994) Students' work experiences, perceptions and attitudes towards careers in hospitality and tourism: a longitudinal case study in Spey Valley, Scotland. International Journal of Hospitality Management, 13(1), 25-37.

Gökdeniz, A., Çeken, H. and Erdem, B. (2002) Okul-sektör işbirliği çerçevesinde stajdan beklentiler, sorunlar ve çözüm önerilerine yönelik bir uygulama. In: Ministry of Tourism (ed.), Proceedings of the conference and workshop on tourism education, 343-367. Ankara: Ministry of Tourism Press.

Jenkins, A. K. (2001) Making a career of it? Hospitality students' future perspectives: an AngloDutch study. International Journal of Contemporary Hospitality Management, 13(1), 13-20.

Kozak, M. and Kızılırmak, İ. (2001) Türkiye'de meslek yüksekokulu turizm- otelcilik programı öğrencilerinin turizm sektörüne yönelik tutumlarının demografik değişkenlere göre değişimi. Anatolia: Turizm Araştırmaları Dergisi, 12, 9-16.

Kuşluvan, S. and Kuşluvan, Z. (2000) Perceptions and attitudes of undergraduate tourism students towards working in the tourism industry in Turkey. Tourism Management, 21(3), 251-269.

Mann, P. S. (1998) Introductory Statistics ( $3^{\text {rd }}$ Edition). USA: John Wiley \& Sons.

ÖSYM (Centre for Student Selection and Placement) (2005) 2005 Yükseköğretim Programları ve Kontenjanları Kılavuzu, Ankara: Öğrenci Seçme ve Yerleştirme Merkezi.

Purcell, K. and Quinn, J. (1995) Hospitality Management Education and Employment Trajectories, Oxford: School of Hotel and Catering Management.

Riley, M., Ladkin, A. and Szivas, E. (2002) Tourism Employment: Analysis and Planning. Clevedon: Channel View Publications.

Ross, G. F. (1994) What do Australian school leavers want of the industry? Tourism Management, 15(1), 62-66.

Sekaran, U. (2003) Research methods for business: a skill building approach (fourth edition). USA: John Wiley \& Sons. 
Akış Roney and Öztin (2007) Career Perceptions of Undergraduate Tourism Students: A Case Study in Turkey

TÜRSAB (2004) R\& D Department Report, March 2004.

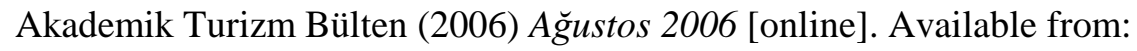

http://www.anatoliajournal.com/turizmbulteni [Accessed 4 September 2006].

Yüksel, F., Yüksel, A. and Hançer, M. (2003). Work expectations of tourism and hospitality internship students and the industry performance, Journal of Travel and Tourism Research, 3(1-2), $12-20$. 


\section{Appendix}

\section{Questionnaire}

The aim of this survey is to understand how undergraduate tourism students at Boğaziçi, Bilkent, and Anadolu Universities perceive tourism careers in Turkey. It will take approximately ten minutes to fill out the questionnaire. Since your response will be kept strictly confidential, please do not write down your name. Your frank and honest answers are very important for us in order to provide a correct picture of your perceptions. Please answer the questions after reading them very carefully. Thank you in advance for your contribution.

\section{GENERAL INFORMATION}

1. The name of your university:

a. Boğaziçi University

b. Bilkent University

c. Anadolu University

2. Your gender:

a. Female

b. Male

3. What grade are you in?

a. Freshman

b. Sophomore

c. Junior

d. Senior

4. Did you graduate from a vocational school of tourism and hotel management?

a. yes

b. no

5. Did you choose your department willingly?

a. yes

b. no

c. I was not very willing

6. What was your rank of preference of the enrolled tourism and management school in the university entrance exam?

a. Between 1-5

b. Between 6-10

c. Between 11-15

d. 16 and lower

7. Do you have any practical work experience in the tourism industry?

a. Yes

b. No

8. If your answer is yes, what is the total number of working days you have spent in the tourism industry? days 
9. In what type(s) of tourism related businesses did you work? (You can circle more than one answer.)

a. Hotel

b. Holiday village

c. Travel agency / Tour operator

d. Airline company

e. Restaurant / Bar

f. Other (please indicate):

10. Do you intend to work in the tourism industry after graduation?
a. Yes
b. No
c. Undecided

11. If your answer is yes, what is (are) your preference(s) for working in specific tourism sector(s) after graduation? (You can circle more than one answer.)

a. Accommodation

b. Travel agency / Tour operator

c. Air transportation

d. Food and beverages

e. Entertainment

g. Other (please indicate):

12. Five years after graduation from this school, what level of position do you expect to have?

13. Do you have any friends / relatives who work in the tourism industry?

a. Yes

b. No

\section{TOURISM CAREERS}

Please tick the appropriate category which best describes how strongly you agree or disagree with each statement given below.

14. Promotion opportunities are satisfactory in the tourism industry.

(1)

Strongly

Disagree
(2)

Disagree
(3)

Neither agree nor disagree
(4)

Agree

Strongly

Agree

15. Tourism related jobs are more respected than the other jobs.

(1)

Strongly

Disagree
(2)

Disagree
(3)

Neither agree nor
(4)

Agree
(5)

Strongly

Agree

16. To study tourism management at the university level is a correct investment in career development.

(1)

Strongly

Disagree
Disagree
(3)

Neither agree nor disagree
(4)

Agree

Strongly

Agree

17. One can make good money by working in tourism.

(1)

Strongly

Disagree
(2)

Disagree
(3)

Neither agree nor disagree
(4)

Agree
(5)

Strongly

Agree 
18. Working in tourism does not provide a secure future.

(1)

Strongly

Disagree
(2)

Disagree
(3)

Neither agree nor disagree
(4)

Agree

(5)

Strongly

Agree

19. Irregular working hours in tourism affects family life negatively.

(3)

(4)

Agree

Strongly

Agree

Disagree
Neither agree nor disagree

21. It is not necessary to have a university degree to work in the tourism industry.

(1)

Strongly

Disagree
(2)

Disagree
(3)

Neither agree nor

disagree
Strongly Agree

(4)

Agree

(4)

Agree

Strongly

Agree

22. It is hard to find job security in tourism.

(1)

Strongly

Disagree
(2)

Disagree
Disagree

Neither agree nor disagree
Agree
Strongly Agree

23. Since many of the managers in tourism do not have a university degree, they are jealous of university graduates working in the industry.

Strongly

Agree

Disagree

Disagree

Neither agree nor disagree

Strongly

Agree

24. There is no sexual discrimination in tourism.

(1)

Strongly

Disagree
(2)

Disagree
(3)

Neither agree nor disagree
(4)

Agree
(5)

Strongly Agree

25. In general, the advantages of working in the tourism industry outweigh the disadvantages.

(1)

Strongly

Disagree
(2)

Disagree
(3)

Neither agree nor disagree
(4)

Agree
(5)

Strongly

Agree 